\title{
PRODUKCJA W ROLNICTWIE W KONTEKŚCIE OCHRONY ŚRODOWISKA
}

\author{
Justyna Góral, Włodzimierz Rembisz \\ Zakład Zastosowań Matematyki w Ekonomice Rolnictwa IERiGŻ-PIB \\ Kierownik zakładu: prof. dr hab. Włodzimierz Rembisz
}

\begin{abstract}
Słowa kluczowe: produkcja rolna, środowisko, zrównoważona intensyfikacja, indeks produktywności uwzględniający aspekty środowiskowe

Key words: agriculture production, environment, sustainable intensification, EnvironmentallyAdjusted Total Factor Productivity
\end{abstract}

\begin{abstract}
S y n o p s i s. Głównym celem pracy było pokazanie konieczności wkomponowania aspektów środowiskowych do teorii produkcji w rolnictwie i pomiaru produktywności. Opracowanie ma charakter metodyczny i przeglądowy. Odnosi się do jednego z problemów współczesnej ekonomii - dylematu pomiędzy skalą gospodarowania zasobami środowiska a efektywnością alokacyjną w gospodarowaniu środowiskiem. W trosce o stan dóbr publicznych konieczny staje się wybór między industrialnym modelem rolnictwa a modelem rolnictwa społecznie zrównoważonego, przy czym ten ostatni staje się modelem wzorcowym. Autorzy przybliżyli zagadnienie produkcji integrowanej oraz zrównoważonej intensyfikacji. W pracy omówiono też nowsze podejście do dotychczasowych miar produktywności gospodarstw rolnych. Przedstawiono indeks produktywności uwzględniający aspekty środowiskowe (tzw. Environmentally Adjusted Total Factor Productivity). Obecnie rolnictwo europejskie kształtowane przez wspólną politykę rolną najpełniej w skali globalnej realizuje koncepcję intensyfikacji i zrównoważonego rozwoju. Jednocześnie znajduje się na ścieżce rozwojowej pozwalającej na konwergencję obu tych koncepcji. Pożądane jest, aby na tę samą ścieżkę wkroczyło również rolnictwo USA i Chin.
\end{abstract}

\section{WPROWADZENIE}

Industrialny model rolnictwa, zorientowany na koncentrację i intensyfikację produkcji [Pawlak 2015], zestawiono z modelem zrównoważonym, zakładającym pełniejszą internalizację kosztów produkcji rolniczej i wynagradzanie rolników za dostarczanie dóbr publicznych. Andrzej Czyżewski [Czyżewski 2015] czy Józef Zegar [Zegar 2014] wskazywali, że założenia przyjmowane w modelu industrialnym nie są możliwe do spełnienia na wszystkich płaszczyznach aktywności gospodarczej (ekonomicznej, społecznej, środowiskowej). Przesłanką do zwrócenia większej uwagi na model rolnictwa społecznie 
zrównoważonego ${ }^{1}$ jest ewolucja wspólnej polityki rolnej (WPR). Unijna polityka ekologiczna oraz przepisy prawne dotyczące ochrony środowiska determinują kierunek rozwoju europejskiego rolnictwa [Piekut, Pawluśkiewicz 2016].

Naturalne (ekologiczne) bariery wzrostu i ograniczoność zasobów akcentowali już wcześniej wybitni ekonomiści, jak: Adam Smith (1723-1790), Thomas Robert Malthus (1766-1834), Jean Baptiste Say (1767-1832), David Ricardo (1772-1823), John Stuart Mill (1806-1873), Karol Marks (1818-1883) i William Stanley Jevons (1835-1882). Ograniczoność zasobów ma istotne znaczenie nie tylko z perspektywy ekonomii, ale także w wymiarze pozaekonomicznym (ang. amenity uses).

Ochrona środowiska staje się priorytetem wielu polityk Unii Europejskiej (UE) i zarazem jednym z najważniejszych wyzwań. Świadczy o tym m.in. treść takich dokumentów, jak: „Polityki horyzontalne Unii Europejskiej” czy „Strategia Europa 2020”. W rolnictwie państw UE są już wdrażane projekty z tego zakresu (cross-compliance, Program Rolnośrodowiskowo-Klimatyczny w ramach Programu Rozwoju Obszarów Wiejskich 2014-2020), a w przyszłości będzie ich jeszcze więcej (zaostrzenie przepisów dotyczących emisji gazów cieplarnianych oraz salda sekwestracji dwutlenku węgla ${ }^{2}$ ).

Rolnictwo operuje na styku trzech podstawowych wymiarów aktywności gospodarczej, co w sytuacji, gdy dwa z nich (społeczny i środowiskowy) nie są ujmowane w rachunku ekonomicznym, prowadzi do rezultatów sprzecznych z racjonalnością gospodarowania. W przypadku rolnictwa industrialnego w sferze ekologicznej wymienić można zanik bioróżnorodności, zanieczyszczenie i erozję gleb oraz nadmierną konsumpcję zasobów wodnych, natomiast w sferze społecznej - utratę żywotności obszarów wiejskich łącznie ze zmianami kulturowymi i występowanie różnorakich chorób związanych z produkowaną w sposób masowy żywnością [Krasowicz 1996, 2008]. Co więcej, również w sferze ekonomicznej uwidaczniają się jego niedostatki teoretyczne. Ujmowane jest to w modelu równowagi wzrostu w sektorze rolno-spożywczym abstrahującym jednak od kwestii środowiskowych [Rembisz 2008]. Okazuje się, że żaden ze stosowanych do tej pory modeli rolnictwa nie doprowadził do ostatecznego rozwiązania kwestii agrarnej, a jedynie częściowo łagodził jej negatywne konsekwencje [Czyżewski, Matuszczak 2011].

Niezaprzeczalnie przyszłość rolnictwa zależy od wdrożenia nowego paradygmatu, odpowiadającego potrzebom zrównoważenia produkcji rolnej i uwzględniającego $\mathrm{w}$ rachunku kosztów nie tylko czynniki czysto ekonomiczne, lecz także te o charakterze społecznym i ekologicznym [Zegar 2005, 2007]. Rolnictwo z jednej strony jest sektorem wysoce specyficznym, wymagającym instytucjonalnego wsparcia, z drugiej zaś, dopiero właściwe ukierunkowanie tej pomocy stwarza możliwość oddziaływania na wielu płaszczyznach, przy relatywnie niewielkim nakładzie środków. W teorii ekonomii model rolnictwa zrównoważonego wydaje się być kolejnym stadium ewolucji polityki rolnej. Ta ewolucja WPR stanowi najsilniejszy przejaw odchodzenia od paradygmatu rolnictwa industrialnego

\footnotetext{
Augustyn Woś wskazywał na niejednoznaczność terminu „rolnictwo zrównoważone” w literaturze światowej i, dokonując jej przeglądu, określił cechy wspólne definicji: wykorzystanie zasobów naturalnych w sposób umożliwiający ich samoodnawianie; przyrost produkcji rolnej osiągany jedynie drogą wzrostu produkcyjności zasobów, a nie zużywania ich; mała podatność rolnictwa zrównoważonego na wahania i wstrząsy; symbioza celów rolniczych i ekoregionalnych [Woś 1992]. Także Edward Majewski wskazywał na niejednoznaczność i ogólnikowość tego terminu, bowiem pod koniec lat 80. ubiegłego wieku ekonomista środowiskowy John Pezzey zidentyfikował ponad 60 definicji zrównoważonego rozwoju, w kolejnej dekadzie Michael Jacobs ustalił aż 386 definicji, a następnie Archie B. Carroll nawet ponad 500 [Majewski 2008].

2 Warto podkreślić, że gospodarstwa z ujemnym saldem emisji gazów cieplarnianych z gleby w porównaniu z gospodarstwami z saldem dodatnim były w lepszej sytuacji ekonomicznej i charakteryzowały się większym nasileniem inwestycyjnym [Zieliński 2014].
} 
na rzecz jego zrównoważenia [OECD 2011, 2014]. Najpełniej zaś postulat zrównoważenia rolnictwa objawia się w zmianach, jakie nastąpiły we WPR na lata 2014-2020, gdzie po raz pierwszy konkretna część dopłat przekazana będzie rolnikom za dostarczanie konkretnych dóbr publicznych. Wydarzenie to stanowić może krok w kierunku ustanowienia powszechnego podatku ekologicznego, z którego środki przeznaczone zostaną na opłatę wytwarzanych przez rolnictwo środowiskowych dóbr nierynkowych [Czyżewski 2015].

Przyjmuje się, że rachunek paradygmatu industrialnego, przez pominięcie wielu niemierzalnych negatywnych efektów działalności, zawyża osiągane efekty. Rachunek zrównoważony zaś, ze względu na trudność wyceny usług publicznych, które gospodarstwa świadczą na rzecz społeczeństwa, cechuje się wynikiem ekonomicznym permanentnie zaniżonym. Kwestia sprowadzenia tych dwóch kategorii pomiaru do „wspólnego mianownika” stanowi obecnie jedno z największych wyzwań ekonomii. Specyfika produkcji rolniczej wynika nie tylko z wykorzystywania nakładu w postaci ziemi rolnej, ale również uzależnienia od warunków klimatycznych. Ponadto, przyjmuje się zgodnie z paradygmatem zrównoważonego rozwoju rolnictwa, że produkcja ta powinna odbywać się w trosce o stan środowiska naturalnego. Wymusza to poszukiwanie adekwatnych miar i sposobów jej ewaluacji.

W pracy omówiono nowe podejście do dotychczasowych miar produktywności gospodarstw rolnych. Przedstawiono indeks produktywności uwzględniający również aspekty środowiskowe (tzw. Environmentally-Adjusted Total Factor Productivity). Głównym celem było pokazanie możliwości wkomponowania aspektów środowiskowych do dotychczasowych teorii produkcji w rolnictwie.

\section{OCHRONA ŚRODOWISKA W GOSPODARSTWACH ROLNICZYCH}

Podmioty gospodarcze są zobligowane do gromadzenia i przechowywania danych $\mathrm{z}$ zachowaniem zasad określonych w ustawie i udostępniania ich na potrzeby państwowego monitoringu środowiska (w zakresie: jakości powietrza i wód śródlądowych, powierzchniowych i podziemnych, jakości gleby i ziemi, hałasu, promieniowania jonizującego i pól elektromagnetycznych, stanu zasobów środowiska, rodzajów i ilości substancji lub energii wprowadzanych do powietrza, wód, gleby i ziemi, wytwarzania i gospodarowania odpadami).

Podstawowe prawa i obowiązki obywateli wobec środowiska określa Konstytucja Rzeczypospolitej Polskiej z dnia 2 kwietnia 1997 r. [Dz.U. 1997.78.483, za: Ochrona... 2010]). Za działania związane z ochroną środowiska przepisy określają odpowiedzialność cywilną, karną i administracyjną.

Rolnictwo, które użytkuje ponad 60\% ogólnej powierzchni kraju, wywiera znaczący wpływ na środowisko. Działalność produkcyjna w rolnictwie może negatywnie oddziaływać na wody powierzchniowe i podziemne, glebę czy powietrze. Niewłaściwe stosowanie przemysłowych środków produkcji, takich jak: nawozy sztuczne i środki ochrony roślin, może prowadzić do zaniku naturalnej flory i fauny, zakłócać gospodarkę wodną i mikroklimat, a w konsekwencji niekorzystnie wpływać na wiele ekosystemów. Rolnictwo bezpośrednio użytkuje zasoby przyrody w procesach produkcji. Z drugiej strony, rolnicy funkcjonujący w gospodarce rynkowej muszą produkować zgodnie z potrzebami społecznymi i jednocześnie maksymalizować swoje funkcje celu poprzez efekty produkcyjne oraz ekonomiczne w warunkach konkurencji. Osiąganie mikroekonomicznych celów produkcyjnych i ekonomicznych producentów w rolnictwie nie zawsze idzie w parze z celami środowiskowymi i ogólnospołecznymi. 
Ochrona środowiska jest obecnie jednym z priorytetów polityki UE i zarazem jednym z najważniejszych wyzwań. Zasady ochrony środowiska oraz troska o stan dóbr publicznych są coraz bardziej wymagane przepisami prawa. W odniesieniu do działalności rolniczej istnieją również wymagania względem funkcjonowania gospodarstw (cross-compliance). Rolnicy ubiegający się o dopłaty bezpośrednie zobowiązani są do przestrzegania tych zasad i utrzymywania gruntów rolnych w dobrej kulturze. W celu ochrony przyrody na gruntach ornych podejmowane są działania polegające na:

- wprowadzaniu wielogatunkowego płodozmianu,

- stosowaniu poplonów: wsiewek, poplonów ścierniskowych i ozimych,

- zakładaniu pasów zadrzewień i nasadzeń śródpolnych,

- utrzymaniu w należytym stanie gruntów ugorowanych i odłogowanych,

- wdrażaniu zasad dobrej praktyki rolniczej,

- zabranianiu wypalania roślinności na łąkach, pastwiskach, nieużytkach rolnych, rowach, ścierniskach, trzcinowiskach i szuwarach,

- wdrażaniu programów rolnośrodowiskowych.

Funkcjonujący w kraju w ramach PROW Program Rolnośrodowiskowo-Klimatyczny jest głównym przedsięwzięciem w systemie ochrony przyrody i krajobrazu na wsi skierowanym bezpośrednio do gospodarstw rolnych. Działanie to ma na celu czynne włączenie producenta rolnego w poprawę jakości środowiska i zachowania walorów przyrodniczych obszarów wiejskich.

Ponadto, należy podkreślić, że przedsięwzięcia inwestycyjne w rolnictwie, związane z chowem lub hodowlą zwierząt w liczbie nie niższej niż 60 DJP (dużych jednostek przeliczeniowych) inwentarza zostały zakwalifikowane do przedsięwzięć mogących znacząco oddziaływać na środowisko [www.odr.pl].

Aktualnie jednym z najważniejszych aspektów gospodarowania na obszarach wiejskich jest działanie zgodne z prawami przyrody, nienaruszające stanu środowiska naturalnego oraz przyczyniające się do zmniejszenia emisji $\mathrm{CO}_{2}$. System ekologiczny (rolnictwo ekologiczne) oraz system produkcji integrowanej są traktowane jako preferowane systemy gospodarowania z uwagi na dostarczanie żywności wysokiej jakości na rynek oraz pozytywny wpływ takiego gospodarowania na jakość gleb, wód oraz na utrzymanie bioróżnorodności [Krasowicz 1996].

\section{ZRÓWNOWAŻONA INTENSYFIKACJA - ZARYS ZAGADNIENIA}

Zrównoważona intensyfikacja - SI (ang. sustinable intensification) to pojęcie, które jest coraz częściej używane i zalecane w odniesieniu do produkcji rolniczej na świecie. SI wymaga jednak pragmatycznych i zarazem innowacyjnych rozwiązań w zakresie polityk rolnych na świecie [Franks 2014]. Aby zachęcać rolników do stosowania praktyk przyjaznych klimatowi czy środowisku, niezbędne są właściwe polityki oddziałujące na mechanizmy rynkowe. Zastosowanie nowych technik może wiązać się z pewnymi utrudnieniami, np. koniecznością wykorzystania dodatkowej siły roboczej, dlatego odpowiednie sposoby zapewnienia udziału rolników są kluczowe dla sukcesu tej idei. Podejścia: zrównoważona intensyfikacja i inteligentne klimatycznie rolnictwo - CSA (ang. climate-smart agriculture) są względem siebie komplementarne. Dzięki adaptacji SI oraz dzięki naciskowi na poprawę zarządzania ryzykiem, informacjami i lokalnymi instytucjami wspierającymi zdolności 
adaptacyjne możliwy jest rozwój CSA [FAO 2011a, 2011b]. Sektor rolny odpowiedzialny jest za 13,7\% światowej emisji gazów cieplarnianych (GHG), dlatego należy podjąć działania mające na celu ograniczenie emisji tych gazów. Realną alternatywę stanowi rolnictwo przyjazne klimatowi (CSA). Przez to pojęcie rozumie się ukierunkowanie praktyk rolniczych na zmniejszenie jego negatywnego wpływu na środowisko, a w konsekwencji także na klimat. Rolnictwo przyjazne klimatowi jest całościowym sposobem odpowiedzi na powiązane ze sobą wyzwania w zakresie bezpieczeństwa żywnościowego i zmian klimatu. Ten model rolnictwa stara się osiągnąć trzy główne cele:

- w sposób zrównoważony podnieść wydajność produkcji rolnej, aby zapewnić wzrost dochodów gospodarstw rolnych, bezpieczeństwo żywnościowe i rozwój obszarów wiejskich;

- na różnych poziomach zwiększyć dostosowanie systemów rolnych i żywnościowych do zmian klimatu oraz odporność na ich konsekwencje;

- zmniejszyć emisję gazów cieplarnianych z rolnictwa (w tym z produkcji roślinnej, hodowli zwierząt i rybołówstwa).

W rolnictwie przyjaznym klimatowi dąży się do realizacji tych celów jednocześnie, na różnych poziomach i w różnych perspektywach czasowych. Pozwala uwzględniać różne krajowe priorytety i lokalną specyfikę [Żukowska i in. 2016; http://dlaklimatu.pl/ rolnictwo-przyjazne-klimatowi/].

Początkowo pojęcie SI było stosowane (w połowie lat 90. XX wieku) w kontekście rozwoju produkcji żywności w Afryce. W raporcie opublikowanym przez The Royal Society SI opisano jako system, w którym zwiększenie wydajności produkcji rolnej odbywa się bez negatywnych skutków dla środowiska [Baulcombe i in. 2009]. Z raportu tego wynika, że zintegrowana intensyfikacja powinna: (1) przyczynić się do zwiększenia produkcji rolnej, (2) spowodować wzrost poziomu ochrony środowiska, (3) nie pociągać za sobą przekształcania ziemi nieużytkowanej rolniczo w ziemię rolną.

Zrównoważona intensyfikacja jest globalną koncepcją, której źródłem jest konstatacja, że rosnący popyt na żywność w warunkach ograniczonych naturalnych zasobów wytwórczych wymaga, aby producenci rolni produkowali więcej żywności, zwiększając wydajność produkcji. Dobrym przykładem sukcesu zrównoważonej intensyfikacji jest współrzędna uprawa kawy i bananów. Coraz więcej przykładów pokazuje, że zrównoważona intensyfikacja drobnego rolnictwa odgrywa ważną rolę w transformacji globalnego sektora żywnościowego na bardziej przyjazny dla klimatu [Campbell i in. 2014].

Pogłębione uzasadnienie dla zmiany paradygmatu rozwoju rolnictwa w skali globu przyniosła publikacja zespołu Allana Buckwella, który zdefiniował zrównoważoną intensyfikację jako stałe podwyższanie wydajności produkcji i poprawę prośrodowiskowego zarządzania ziemią rolniczą [Buckwell i in. 2014]. Formułując postulat „więcej wiedzy na hektar” (ang. ,,more knowledge per hectar”), naukowcy wpisali się w dyskusję o konieczności znaczącego wzrostu nakładów na badania i rozwój w rolnictwie, bez którego zrównoważona intensyfikacja nie jest możliwa. Zdaniem Iwony Nurzyńskiej, Europa musi koncentrować się na pierwszym członie koncepcji zrównoważonej intensyfikacji, tj. dążąc do modelu zrównoważonego rolnictwa, kładąc większy nacisk na zachowanie i ochronę zasobów natury oraz adaptację do zmian klimatu [Nurzyńska 2015].

Reasumując, realizacja koncepcji zrównoważonej intensyfikacji w UE powinna skupić się na dążeniu do zrównoważenia produkcji rolnej, co zagwarantuje zachowanie i ochronę cennych zasobów rolniczych. Dalsza intensyfikacja przez większą specjalizację i koncen- 
trację produkcji nie jest pożądana ${ }^{3}$ Z uwagi na fakt, że unijne rolnictwo w większości jest zdominowane przez rodzinne gospodarstwa rolne, zasady SI powinny być w nim tym bardziej realizowane. Konieczne jest zwiększenie tempa wzrostu wydajności produkcji rolniczej, ale musi ono odbywać się metodami integrującymi cele ekonomiczne ze środowiskowymi. Niezbędne jest do tego podniesienie poziomu innowacyjności w rolnictwie. Właściciele największych gospodarstw rolnych ${ }^{4}$ powinni pogodzić się w przyszłości z coraz liczniejszymi ograniczeniami w zakresie dalszego intensyfikowania produkcji przy obecnie stosowanych technologiach produkcji. Wytyczne odnośnie polityki ochrony środowiska trzeba będzie uwzględniać nie tylko w biznesplanach dotyczących przedsięwzięć inwestycyjnych, ale również w bieżących decyzjach produkcyjnych, i traktować środowisko jako kolejny, coraz bardziej cenny czynnik produkcji [López 1994]. Zarówno podczas wyboru kierunku produkcji (specjalizacja), jak i zastosowanej technologii wymaga się od rolnika coraz większej troski o stan dóbr publicznych. W przeciwnym wypadku będzie musiał ponosić wyższe koszty produkcji z uwagi na obciążenia sankcjami za zanieczyszczanie środowiska naturalnego w myśl zasady ,zanieczyszczający płaci”. Można to potraktować jako kolejny warunek w modelowaniu optymalizacyjnym (optymalizacja wielowymiarowa z ograniczeniami). Równolegle aspekty środowiskowe uwzględniane są coraz częściej w indeksach produktywności podczas pomiaru finalnych efektów gospodarowania [Azad, Ancev 2014, Ancev, Azad 2015, http://www.oecd.org].

Intensyfikacja produkcji pozwala na jej zwiększenie nawet przy równoczesnym spadku powierzchni użytków rolnych ${ }^{5}$ lub liczby zwierząt. W przyszłości sektor ten musi być również coraz bardziej efektywny adaptacyjnie. Docelowym europejskim modelem rolnictwa powinno pozostać rolnictwo zrównoważone środowiskowo i społecznie. Obecnie około $30 \%$ gospodarstw rolnych UE to gospodarstwa rodzinne wypełniające postulat trwałości, które cechują się trójwymiarowym zrównoważeniem: ekonomicznym, społecznym i środowiskowym [Poczta 2015].

\section{PRODUKCJA INTEGROWANA - IDEA I ZAŁOŻENIA}

System gospodarowania lub system rolniczy oznacza sposób zagospodarowania przestrzeni rolniczej w zakresie produkcji roślinnej i zwierzęcej oraz przetwarzania ich produktów, wyceniony kryteriami ekonomicznymi i ekologicznymi [Niewiadomski 1993]. Najczęściej wyróżnia się trzy systemy gospodarowania w rolnictwie: konwencjonalny, ekologiczny i integrowany. Alternatywą dla systemu konwencjonalnego mogą być rozwijające się intensywnie systemy ekologiczny oraz integrowany. Kryterium wyróżnienia systemów jest stopień uzależnienia rolnictwa od przemysłowych środków produkcji oraz możliwość realizacji celów zrównoważonego rozwoju [Kuś 1995, Kuś, Stalenga 2006, ARiMR 2011, 2012].

Idea integrowanej produkcji rolnej - IFS (ang. Integrated Farming System) powstała w latach 80. XX wieku w Europie Zachodniej, a u jej podstaw leżała integrowana ochrona roślin - IPM (ang. Integrated Pest Managment), której koncepcja pochodzi z lat 60. XX

3 Wzrost liczby gospodarstw bezinwentarzowych nie jest korzystny dla zrównoważonej produkcji rolnej [Krasowicz 2008]. Problematykę zróżnicowanych systemów rolniczych z uwzględnieniem lokalnej specyfiki i warunków przedstawił Claire Kremen z zespołem [Kremen i in. 2012].

$4 \quad$ Warto podkreślić, że na świecie funkcjonuje około $570 \mathrm{mln}$ gospodarstw rolnych, z czego 1\% użytkuje aż $65 \%$ użytków rolnych globu. Natomiast $72 \%$ gospodarstw posiada powierzchnię UR mniejszą od 1 hektara i łącznie użytkuje tylko 8\% UR na świecie [Poczta 2015].

5 UR na świecie per capita: 1950 r. - 0,5 ha; 2000 r. - 0,3 ha; 2050 r. - 0,2 ha [Poczta 2015]. 
wieku. Przyjmuje się, że przy przejściu od intensywnego gospodarowania konwencjonalnego do systemu integrowanego możliwe jest ograniczenie zużycia przemysłowych środków produkcji (chemicznych środków ochrony roślin i nawozów mineralnych) nawet o 30-50\% i nie powinno to powodować większego niż 3-7-procentowego spadku plonów. Podstawowym czynnikiem warunkującym efektywniejsze wykorzystanie środków produkcji jest wiedza umożliwiająca precyzyjne ustalanie wielkości ich dawek i terminów aplikacji [Kuś 1999].

Integrowana produkcja (IP) jest systemem gospodarowania, który ma na celu zapewnić produkcję żywności wysokiej jakości i innych produktów, wykorzystując zasoby naturalne i mechanizmy regulujące w miejsce środków stanowiących zagrożenie oraz w celu zabezpieczenia zrównoważonego rozwoju. W integrowanej produkcji nacisk położony jest na: (1) holistyczne podejście do systemu, które traktuje całe gospodarstwo jako podstawową jednostkę, (2) centralną rolę agroekosystemu, (3) zbilansowanie cyklu nawożenia, (4) zabezpieczenie dobrostanu wszystkich zwierząt gospodarskich. Niezbędnymi warunkami IP jest ochrona i polepszenie żyzności gleby, różnorodność środowiska oraz kryteria etyczne i socjalne [Pruszyński i in. 2008]. Taką produkcję prowadzi się zgodnie z wytycznymi zatwierdzonymi przez Głównego Inspektora Ochrony Roślin i Nasiennictwa (GIORiN) ${ }^{6}$. Uczestnictwo w systemie IP pozwala na otrzymanie zdrowej żywności pochodzenia roślinnego, w której nie zanotowano przekroczeń dopuszczalnych poziomów pozostałości środków ochrony roślin, metali ciężkich, azotanów i innych pierwiastków oraz substancji szkodliwych. W związku z tym opracowano listę dopuszczonych do IP środków ochrony roślin, którą można odnaleźć na stronach internetowych Instytutu Ogrodnictwa w Skierniewicach (uprawy sadownicze oraz uprawy warzywne) oraz Instytutu Ochrony Roślin - Państwowego Instytutu Badawczego w Poznaniu (uprawy rolnicze). Potwierdzeniem wysokiej jakości plonów jest certyfikat i zastrzeżony znak IP.

Systemy integrowanej ochrony roślin oraz integrowanej produkcji są znane niewielkiej grupie producentów rolnych i znikomej liczbie konsumentów. Integrowana ochrona polega na celowym wykorzystywaniu wszelkich sposobów wpływania na zdrowie roślin i ich odporność na choroby, szkodniki i chwasty. Ważnym założeniem jest to, że chemiczne środki ochrony roślin stosuje się w ostateczności. Zgodnie z dyrektywą Parlamentu Europejskiego i Rady Europy ustanawiającą ramy wspólnotowego działania na rzecz zrównoważonego stosowania pestycydów, od 1 stycznia 2014 r. państwa członkowskie mają obowiązek wdrożenia zasad integrowanej ochrony roślin [Dyrektywa 2009/128/WE z 21 października 2009 r., Integrowana ... 2012]7 . Obowiązki wynikające ze stosowania tych zasad są elementami systemu wzajemnej zgodności cross-compliance. Od spełnienia tych wymagań zależy uzyskanie przez rolników płatności bezpośrednich [Niewęgłowska 2013]. Jednostki certyfikujące prowadzą rejestr producentów rolnych, którzy zgłosili zamiar stosowania IP, oraz kontrolują tych producentów rolnych. Państwowa Inspekcja Ochrony Roślin i Nasiennictwa prowadzi z kolei nadzór nad jednostkami certyfikującymi [http:// www.farmer.pl/, Niewęgłowska 2013].

Zatwierdzone metodyki IP są dostępne pod adresem: http://piorin.gov.pl/index.php?pid=1477.

W 1991 r. zapoczątkowano integrowaną produkcję jabłek, a w dziesięć lat później według tej technologii 1180 sadowników produkowało jabłka na areale ponad 7300 ha. W tym okresie opracowano integrowane technologie produkcji truskawek (1995 r.), grusz (1997 r.) i wiśni (1992 r.). W 2006 r. GIORiN wydał 1891 certyfikatów obejmujących powierzchnię 10924 ha upraw, z czego jabłka zajmowały 7635 ha [PIORiN 2007]. W 2007 r. GIORiN zatwierdził metodykę integrowanej produkcji rzepaku ozimego i jarego. W 2008 r. zaakceptowano metodyki integrowanej produkcji kukurydzy, pszenicy i jęczmienia, które przy udziale badaczy z innych jednostek, opracowano w Instytucie Ochrony Roślin w Poznaniu [Pruszyński i in. 2008]. 
E. Majewski, prowadząc na terenie Mazowsza pilotażowe doświadczenie wdrożeniowe integrowanej produkcji, stwierdził, że $w$ polskich warunkach, gdy mamy do czynienia z rolnictwem niskonakładowym, obarczonym wieloma błędami technologicznymi oraz nienajlepsza organizacja pracy, wdrożenie integrowanej produkcji może przynieść znaczne efekty ekonomiczne. Przy zmniejszonej dawce nawozów, dzięki poprawnej agrotechnice i zmniejszeniu intensywności chemicznej ochrony roślin, ale i poprawie jakości plonów, dochód rolniczy w grupie badanych gospodarstw byt ponad 2,5 razy wyższy w porównaniu do grupy kontrolnej [Majewski 2005, s. 92].

Reasumując, należy uwzględnić znaczenie czynników: środowiskowego, społecznego i rynkowego integrowanych technologii. Czynniki te mają podstawowe znaczenie dla przyszłości rolnictwa.

\section{PRODUKTYWNOŚĆ A ŚRODOWISKO}

Badania produktywności coraz częściej są poszerzane o analizy emisji dwutlenku węgla generowanego $\mathrm{w}$ gospodarstwie rolnym. Jest to pochodna nakreślanych wyzwań względem problemów dotyczących zmian klimatycznych i rosnącej populacji ludzi na świecie. W najnowszych wytycznych dla polityk UE (polityki horyzontalne, „Strategia Europa 2020”, WPR) położono nacisk na ograniczanie emisji gazów cieplarnianych oraz na upowszechnianie nowych, przyjaznych dla środowiska technologii (zgodnie z hipotezą Michaela Portera $\left.{ }^{8}\right)$. Wiele nowych regulacji prawnych i wytycznych w tym zakresie coraz częściej determinuje decyzje produkcyjne rolników. Nowe ograniczenia wymuszają na producentach rolnych w sposób bezpośredni lub pośredni większą troskę o stan środowiska czy, ogólnie ujmując, o stan dóbr publicznych. Pojawiają się nowe sposoby ujmowania tych środowiskowych regulacji w tradycyjnych pomiarach produktywności (koszty zanieczyszczania środowiska czy emisji gazów cieplarnianych, udział w realizacji poszczególnych projektów środowiskowych). Koszty zanieczyszczania środowiska są ujmowane podczas estymacji modeli czy funkcji produkcji (wycena środowiska jako czynnika produkcji w środowiskowej funkcji produkcji - environmental production function). Koszty zanieczyszczania środowiska ujmowane są jako jeden z nakładów (danych wejściowych) do modelu lub też jako utracona (zaniechana) wartość produkcji w związku z przestrzeganiem ograniczeń środowiskowych. Można zatem badać i analizować nieefektywność techniczną w zależności od poziomu kosztów zanieczyszczania środowiska. Założono, że:

nakłady oznacza się jako $x$, gdzie: $x=\left(x_{1}, \ldots, x_{N}\right) \in R_{+}^{N}$,

pożądane efekty jako $y$, gdzie: $y=\left(y_{1}, \ldots, y_{N}\right) \in R_{+}^{N}$,

niepożądane efekty (np. $\mathrm{SO}_{2}$ lub $\mathrm{CO}_{2}$ w tonach) jako $b$, gdzie: $b=\left(b_{1}, \ldots, b_{J}\right) \in R_{+}^{J}$,

technologię produkcji wyznacza formuła:

$P(x)=\{(y, b): x$ może dawać $(y, b)\}, x \in R_{+}^{N}$.

W 1991 r. M. Porter w artykule opublikowanym w „Scientific American” zaproponował całkowicie odmienne podejście. Jego zdaniem, powstawanie zanieczyszczeń i odpadów w procesie produkcji jest pewnego rodzaju stratą i świadczy o nieefektywnym wykorzystaniu zasobów środowiska przyrodniczego. Zatem eliminując powstawanie zanieczyszczeń przez zmiany organizacyjno-zarządcze oraz technologiczne, przedsiębiorstwa mogą jednocześnie obniżać swoje oddziaływanie na środowisko oraz podnosić konkurencyjność [Kudłak 2010, Kulawik 2016].

9 Założenia dla środowiskowej technologii: $\{0\} \in P(x)$ dla wszystkich $x \in R_{+}^{N}, P(x)$ jest zawarty w $x \in R_{+}^{N}$ oraz $P(x) \subset P\left(x^{\prime}\right)$ jeżeli $x^{\prime} \geq x$. 
Rysunek 1. Technologia produkcji z uwzględnieniem czynnika środowiskowego Źródło: [Färe i in. 2007]. $y$ (efekty pożądane)

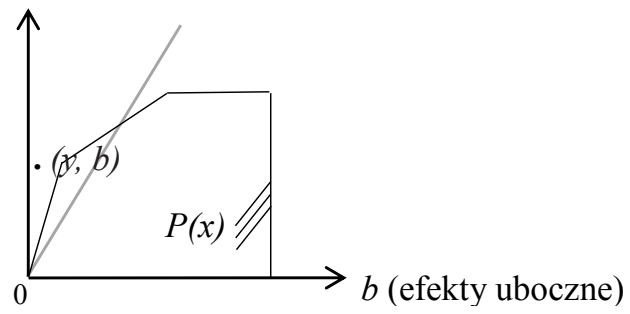

Dla każdego wektora nakładów otrzymujemy zbiór efektów (pożądanych i niepożądanych). Efekty niepożądane określane są jako skutki uboczne. Na rysunku 1. pokazano zbiór potencjalnych, możliwych efektów, czyli punktów $(y, b)$ dla technologii $P(x)$.

Kluczowa i coraz bardziej rozstrzygająca stawać się będzie wielkość $b$, która w tym wypadku obrazuje produkt uboczny (efekt niepożądany) w procesie produkcji. Warto jednak wspomnieć odmienną propozycję Maxa Keilbacha, w której szacował funkcję produkcji typu Cobba-Douglasa ${ }^{10} \mathrm{z}$ uwzględnieniem nakładów w postaci emisji $\mathrm{CO}_{2}, \mathrm{SO}_{2}$ czy $\mathrm{NO}_{\mathrm{x}}$ (prezentując odmienne podejście włączające zanieczyszczanie środowiska do zbioru nakładów) [Keilbach 1995].

Badania dotyczące funkcji produkcji i jednocześnie poświęcone celom ekonomiczno-śro-dowiskowym zawarto również w publikacji zespołu pod kierunkiem Alexandra Macphersona [Macpherson i in. 2009]. Analizy prowadzono w ujęciu regionalnym (przestrzennym) i czasowym (szeregi czasowe). Zespół ten zaproponował nieparametryczną metodę szacowania efektów z wykorzystaniem funkcji odległości w postaci kierunkowej (ang. directional distance function $)^{11}$. Regionalna funkcja produkcji w ujęciu środowiskowo-ekonomicznym (ang. environmental directional distance function) charakteryzowała względną efektywność jednostek w ujęciu geograficznym. Chodziło o to, aby wskazać w zbiorowości podmioty, które gospodarują najlepiej (maksymalizacja pożądanych efektów), ale jednocześnie najmniej szkodzą przyrodzie (optymalnie zarządzają zasobami, w tym również środowiskiem). Nie generują one wówczas istotnych kosztów dla otoczenia zewnętrznego i nie niszczą zasobów dóbr publicznych (w postaci czystych wód, czystego powietrza, dużej bioróżnorodności, itp.), co można określić mianem redukcji internalizacji negatywnych efektów zewnętrznych (redukcja niepożądanych efektów). Warto podkreślić, że zespół Rolfa Färe pokazał zastosowanie funkcji odległości (ang. distance function) do rozwinięcia i udoskonalenia indeksów produktywności Malmqvista (ang. Malmqvist productivity index) [Färe i in. 1994], co szczegółowo zostało rozwinięte w pracach przez Saleema Shaika i Richarda Perrina [Shaik, Perrin 1999] oraz Jona Rezeka i R. Perrina [Rezek, Perrin 2004].

Środowiskowe skutki prowadzenia działalności gospodarczej zostały włączone w ramy modelowania produktywności i efektywności [Tyteca 1996]. Coraz więcej badań poświęconych pomiarowi produktywności i efektywności gospodarstw rolnych uwzględnia

10 Funkcja Cobba-Douglasa to funkcyjne przedstawienie zależności wielkości produkcji $Q$ od nakładów na czynniki produkcji. Funkcja zachowuje zasadę malejących przychodów - każda kolejna jednostka jednego z zasobów bez wzrostu zasobu drugiego skutkuje mniejszym przyrostem produkcji. Jest chętnie wykorzystywana w modelowaniu, gdyż dobrze przedstawia następujące fakty stylizowane, tzn. monotoniczność i wklęsłość.

11 Funkcję odległości będącą odmianą czy też modyfikacją funkcji niedoboru Luenbergera (ang. the Luenberger shortage function) zaproponowano w publikacji [Chung i in. 1997]. 
jednocześnie skutki ich działalności dla środowiska. W publikacjach naukowych coraz więcej uwagi poświęca się indeksom produktywności skorygowanym środowiskowo (ang. environmentally adjusted multi-factor productivity, environmentally adjusted total factor productivity). Wskaźniki produktywności skorygowane środowiskowo pozwalają zidentyfikować działalności produkcyjne, które kreują dużą efektywność ekonomiczną i mają stosunkowo niewielki wpływ na środowisko, a także te mające istotny wpływ na środowisko i jednocześnie skromną wartość ekonomiczną [Ancev, Azad 2015]. Wiele najnowszych podejść do szacowania produktywności ujmuje także efektywność środowiskową [Färe, Grosskopf 2004, Kumar, Khanna 2009, Hoang, Coelli 2011]. Najczęściej bazują one na standardowych indeksach produktywności, ale są stosowane w nowym, szerszym ujęciu z uwzględnieniem efektów środowiskowych ${ }^{12}$. Dzięki temu, analizując dwa gospodarstwa o jednakowej produktywności, można stwierdzić, czy oddziałują one w taki sam sposób na środowisko naturalne. Porównanie takie pozwala znaleźć wzorzec (ang. benchmark).

Warto też nawiązać do badań Chang Gyun Kim i Tai-Yoo Kim, w których zastosowano indeksy produktywności Malmqvista-Luenbergera $(M-L)$ również skorygowane o dane środowiskowe [C.G. Kim, T-Y. Kim 2016]. Analizowali oni środowiskowe koszty osiągania najwyższej efektywności ekonomicznej, przeprowadzone zaś badanie miało na celu uzyskanie odpowiedzi na pytanie, czy najbardziej efektywne ekonomicznie gospodarstwa jednocześnie też najbardziej szkodzą środowisku. Naukowcy wykorzystali nieparametryczne metody programowania liniowego do oszacowania kierunkowej funkcji odległości będącej fundamentem indeksów produktywności M-L.

Wśród wykorzystywanych miar produktywności na uwagę zasługują indeksy Luenbergera - LPI (ang. Luenberger productivity indicator), w których zakłada się maksymalizację zysków/dochodów. Indeksy te stosuje się z użyciem danych w postaci szeregów czasowych. Wymagają one mniej restrykcyjnych założeń. Jednak w przypadku danych środowiskowych pojawia się problem ich nieporównywalności przestrzennej. Poszczególne gospodarstwa mogą różnić się znacząco, jeśli chodzi o obfitość zasobów środowiskowych, ich cenność (zagrożenie wyginięciem jakichś gatunków) oraz trwałość. Tutaj w każdym przypadku należałoby oddzielnie wycenić te walory przyrodnicze, jednak sam proces i sposób oceny są bardzo trudne ${ }^{13}$. Nowe zastosowanie indeksów Luenbergera pozwala uchwycić te regionalne różnice w zasobności walorów przyrodniczych [Ancev, Azad 2015]. Skorygowany środowiskowo indeks produktywności - LEI można przedstawić w postaci równania (4):

$$
\begin{aligned}
L E I_{a}^{b}= & \frac{1}{2}\left[\vec{D}_{o}^{b}\left(x^{a}, d^{a}, u^{a} ; \mathrm{g}_{d},-\mathrm{g}_{u}\right)-\vec{D}_{o}^{b}\left(x^{b}, d^{b}, u^{b} ; \mathrm{g}_{d},-\mathrm{g}_{u}\right)+\vec{D}_{o}^{a}\left(x^{a}, d^{a}, u^{a} ; \mathrm{g}_{d},-\mathrm{g}_{u}\right)\right. \\
& \left.-\vec{D}_{o}^{a}\left(x^{b}, d^{b}, u^{b} ; \mathrm{g}_{d},-\mathrm{g}_{u}\right)\right]
\end{aligned}
$$

gdzie: $x$ - wektor nakładów, $d$-wektor efektów, $u$ - niepożądane efekty zewnętrzne dla środowiska (degradacja), $g$ - kierunkowa funkcja oparta na odległości, $a$ - lokalizacja gospodarstwa w punkcie $a, b$ - lokalizacja porównywanego gospodarstwa, położonego w punkcie $b$, do tego zlokalizowanego w punkcie $a$.

12 J.P. Rezek i R.K. Perrin pokazali wskaźniki produktywności skorygowane o informacje dotyczące zanieczyszczenia środowiska na przykładzie klasycznych miar (tj. indeksów Malmqvista TFP oraz Tornqvista-Theila) [Rezek, Perrin 2004].

13 W literaturze spotyka się zastosowanie metody cen hedonicznych (ang. hedonic price method). Metodę tę stosuje się obecnie do wyceny różnych atrybutów nieruchomości, takich jak cisza, ładny widok, bliskość terenów cennych przyrodniczo, jakość powietrza itp. Należy jednak mieć na uwadze, że jest to metoda pośrednia. 
Na samym początku badania zakłada się, że porównywane jednostki stosują taką samą technologię produkcji. Jeżeli wartość LEI jest większa od zera, oznacza to, że skorygowana środowiskowo produktywność jednostki w regionie $b$ jest większa niż tej znajdującej się w regionie $a$. Jeśli wskaźnik przyjmuje wartość mniejszą od zera, oznacza to, że gospodarstwo w regionie $b$ jest stosunkowo mniej efektywne niż te z regionu $a$.

Reasumując, klasyczny wskaźnik Luenbergera poszerzony o aspekty środowiskowe (ang. environmentally adjusted productivity) ma dwie cechy wyróżniające: (1) ujmuje zmienne na temat poziomu degradacji środowiska w procesie produkcyjnym, (2) umożliwia porównanie względnych produktywności analizowanych podmiotów gospodarczych w ujęciu przestrzennym (regionalnym). Wskaźnik ten może dostarczyć decydentom niezbędnych informacji, które mogą być użyteczne jako wytyczne do formułowania polityki i strategii w kierunku bardziej zrównoważonej produkcji rolnej.

\section{PODSUMOWANIE}

Ochrona środowiska to jedno z najważniejszych wyzwań dzisiejszych czasów. Zasady ochrony przyrody oraz warunki korzystania zjej zasobów z uwzględnieniem wymagań zrównoważonego rozwoju są nakazem dla współczesnego społeczeństwa UE. Istnieją określone wymagania również względem gospodarstw rolnych, zwane zasadami cross-compliance. Rolnicy ubiegający się o dopłaty bezpośrednie są zobowiązani do ich przestrzegania oraz utrzymywania gruntów rolnych w dobrej kulturze. Osiąganie celów produkcyjnych i ekonomicznych najczęściej jednak kłóci się z celami środowiskowymi i ogólnospołecznymi. Nadal bardzo pożądane jest podnoszenie konkurencyjności europejskiego rolnictwa na globalnym rynku. Założenia ekonomii neoklasycznej znajdują tutaj odzwierciedlenie.

Jednak ocena rzeczywistego pomiaru wyników w zakresie produktywności powinna uwzględniać także aspekty środowiskowe. Wpływ technologii produkcji na stan przyrody nie pozostaje bez znaczenia (może pojawiać się internalizacja negatywnych efektów zewnętrznych) i należy go również uwzględniać w postaci konkretnych wskaźników. Badania poświęcone zagadnieniom zanieczyszczania środowiska wymagają zbioru wieloletnich danych oraz prowadzenia rachunkowości z uwzględnieniem danych środowiskowych. Rachunkowość uwzględniająca aspekty środowiskowe to kolejne wyzwanie dla polskich gospodarstw rolnych.

Uboczne efekty środowiskowe prowadzenia produkcji rolnej najczęściej można oszacować. Komisja Europejska dostrzega w poprawie produktywności połączonej ze środowiskowym zrównoważeniem główny cel i strategię działania europejskiego sektora rolnego na kolejne dekady. Do pomiaru realizacji tego celu proponuje się wykorzystanie wskaźnika TFP skorygowanego środowiskowo (ang. environmentally-adjusted TFP, czyli EATFP). Zdaniem ekspertów OECD [OECD 2014], EATFP jest kluczowym wskaźnikiem dla monitorowania postępów zielonego wzrostu (ang. green growth) w rolnictwie. Pod pojęciem green growth kryje się idea zmierzająca do powiązania wzrostu gospodarczego (rozwoju ekonomicznego) i zrównoważenia środowiskowego (redukcji zużycia węgla dzięki rozpowszechnianiu energii odnawialnej). Jednak dotychczasowe informacje i dane z zakresu zanieczyszczania środowiska są zbyt skąpe i konieczne jest wypełnienie tej luki w kolejnych latach. Więcej uwagi należy poświęcić nie tylko emisji gazów cieplarnianych, ale również sekwestracji dwutlenku węgla w glebie. W kolejnych badaniach należy także szacować indeks produktywności węgla (ang. carbon productivity index). 
Reformy WPR mają na celu zachęcić producentów rolnych do zmiany postawy względem dóbr publicznych (do redukcji internalizacji negatywnych efektów zewnętrznych), a także wykorzystywania technologii uwzględniających prośrodowiskowe regulacje prawne i zaostrzenia odnośnie produkcji rolnej (w myśl hipotezy M. Portera ${ }^{14}$ ).

\section{LITERATURA}

Ancev Tiho, Azad Samad Md., 2015: Environmentally Adjusted Productivity and Efficiency Measurement: A New Direction for the Luenberger Productivity Indicator, Selected Paper prepared for presentation at the 2015 Agricultural \& Applied Economics Association and Western Agricultural Economics Association Annual Meeting, San Francisco, July 26-28.

ARiMR, MRiRW, 2011: Integrowana produkcja, „Biuletyn Informacyjny”, nr 3-4, s. 17-18.

ARiMR, MRiRW, 2012: Integrowana produkcja w świetle integrowanej ochrony roślin, „Biuletyn Informacyjny", nr 11, s. 19.

Azad Samad Md., Tiho Ancev, 2014: Measuring environmental efficiency of agricultural water use: a Luenberger environmental indicator, „Journal of Environmental Management”, vol. 145, s. 314-320.

Baulcombe David, Bill Davies, Ian Crute, Jim Dunwell, Mike Gale, Jonathan Jones, Jules Pretty, William Sutherland, Camilla Toulmin, 2009: Reaping the Benefits: Science and the sustainable intensification of global agriculture, London, Royal Society.

Buckwell Allan, Andreas Nordang Uhre, Annabelle Williams, Jana Poláková, Winfried Blum, Jasmin Schiefer, Georg Lair, Alois Heissenhuber, Peter Schie $\beta$, Christine Krämer, Wolfgang Haber, 2014: Sustainable intensification of European agriculture, Rural Investment Support for Europe.

Campbell Bruce M., Philip Thornton, Robert Zougmoré, Piet van Asten, Leslie Lipper, 2014: Sustainable intensification: What is its role in climate smart agriculture? „Current Opinion in Environmental Sustainability", vol. 8, s. 39-43.

Chung Yangho, Rolf Färe, Shawna Grosskopf, 1997: Productivity and Undesirable Outputs: A Directional Distance Function Approach, „Journal of Environmental Management”, vol. 51(3), s. 229-240.

Czyżewski Andrzej, 2015: Teoriopoznawcze przesłanki rozwoju rolnictwa rodzinnego, [w] Ekonomiczne mechanizmy wspierania i ochrony rolnictwa rodzinnego $w$ Polsce $i$ innych państwach Unii Europejskiej, red. Aleksandra Chlebicka, KSOW Warszawa, s. 9-30.

14 Hipoteza ta sugeruje, że restrykcyjne przepisy dotyczące ochrony środowiska przyczyniają się do odkrywania i wprowadzania coraz bardziej ekologicznych technologii (do poprawy stanu środowiska). Efekt innowacji czyni procesy produkcyjne i same produkty bardziej efektywnymi. Oszczędności, które można w ten sposób osiągnąć, są wystarczające, aby zrekompensować zarówno koszty bezpośrednio związane z przestrzeganiem nowych przepisów, jak i koszty wprowadzenia innowacji [Żylicz 2012]. Pewną odmianą hipotezy M. Portera jest wymaganie, aby przedsiębiorstwa ograniczały emisje $\mathrm{CO}_{2}$ nawet wówczas, gdy reszta świata tego nie czyni. Zdaniem Tomasza Żylicza z punktu widzenia globalnej ochrony klimatu (klimat jest dobrem publicznym) owo wymaganie nie ma sensu [Żylicz 2012]. Jednak politycy z Komisji Europejskiej uważają, że takie działanie przyniesie ekonomiczne korzyści producentom w UE. Niewykluczone, że w odległej przyszłości europejskie zaostrzenia okażą się trafne, ale póki co produkcja przenosi się gdzie indziej. Producenci unikają respektowania narzuconych wytycznych [http://coin.wne.uw.edu.pl].

Przenoszenie produkcji kłopotliwych towarów (tzw. pollution haven hypothesis, czyli hipoteza ,przystani dla brudnych przemysłów”) wynika nie tyle stąd, że kraje biedniejsze są zmuszane do ich wytwarzania, co stąd, że w krajach bogatszych ludzie są gotowi ponieść większy koszt, żeby od swoich producentów czegoś wymagać. Przy tej okazji powraca pytanie o to, czy poprawa środowiska nastąpi spontanicznie, jak tylko się ludzie wzbogacą (zgodnie z interpretacją ekologicznej krzywej Kuznetsa), czy jednak wymaga odpowiednich starań i polityki. Wydaje się, że polityka jest niezastąpiona i od jej skuteczności zależy, jaka będzie jakość środowiska przyrodniczego nawet w zamożnym kraju.

Jak dotąd badania dotyczące związku między środowiskową a ekonomiczną działalnością przedsiębiorstw nie przyniosły jednoznacznego rozstrzygnięcia, jednak na ich podstawie można sformułować pewien ogólny pogląd. Można sądzić, że hipoteza wyrażona przez M. Portera opisuje raczej pewną wyjątkową sytuację niż powszechny i uniwersalny mechanizm [Wiszniewska 2009, Kudłak 2010]. 
Czyżewski Andrzej, Anna Henisz-Matuszczak, 2005: Makroekonomiczne uwarunkowania rolnictwa industrialnego i społecznie zrównoważonego. Refleksje na temat sprzężeń regulacyjnych i realnych, [w] Koncepcja badań nad rolnictwem społecznie zrównoważonym red. Józef St. Zegar, Program Wieloletni 2005-2009, Monografia nr 11, IERiGŻ-PIB, Warszawa, s. 53-70.

FAO, 2011a: Climate-Smart Agriculture: Smallholder Adoption and Implications for Climate Change Adaptation and Mitigation, Rome, Italy, December 2011, s. 7-18.

FAO, 2011b: FAO-Adapt: Framework Programme on Climate Change Adaptation, Rome.

Färe Rolf, Shawna Grosskopf, Mary Norris, Zhongyang Zhang, 1994: Productivity Growth, Technical Progress, and Efficiency Change in Industrialized Countries, „The American Economic Review”, vol. 84, no. 1, s. 66-83, http://www.jstor.org/stable/2117971.

Färe Rolf, Shawna Grosskopf, 2004: New Directions: Efficiency and Productivity, Kluwer Academic Publishers, Boston, s. 45-91.

Färe Rolf, Shawna Grosskopf, Carl Pasurka, 2007: Environmental production functions and environmental diretional distance functions, „Energy”, no. 32, s. 1055-1066.

Franks Jeremy, 2014: Sustainable intensification: A UK perspective, „Food Policy”, vol. 47, s. 71-80.

Hoang Viet-Ngu, Timothy Coelli, 2011: Measurement of agricultural total factor productivity growth incorporating environmental factors: A nutrients balance approach, ,Journal of Environmental Economics and Management", vol. 62, issue 3, s. 462-474.

Integrowana ochrona roślin $w$ gospodarstwie. Poradnik praktyczny - zasady ogólne, Centrum Doradztwa Rolniczego w Brwinowie, Oddział w Radomiu, 2012, Radom, s. 6-12.

Keilbach Max, 1995: Estimating the marginal product of emission in a country, where emission output is regulated, „Environmental and Resource Economics”, vol. 5, s. 305-319.

Kim Chang Gyun, Tai-Yoo Kim, 2016: Using a directional distance function approach to value environmental services: the case of legume-based cropping systems and symbiotic nitrogen, http://www.webmeets.com/files/papers/EAERE/2016/108/Shadow\%20pricing\%20ES.pdf.

Krasowicz Stanisław, 1996: Analiza i ocena gospodarstw ekologicznych, integrowanych i tradycyjnych w rejonie Polski Pótnocno-Wschodniej na tle warunków przyrodniczych i ekonomicznych rolnictwa, Rozprawa habilitacyjna, IUNG Puławy, s. 5-39.

Krasowicz Stanisław, 2008: Ocena możliwości zrównoważonego rozwoju gospodarstw bezinwentarzowych, [w] Z badań nad rolnictwem społecznie zrównoważonym (5), red. Józef. St. Zegar, Program Wieloletni 2005-2009, nr 87, s. 11-38.

Kremen Claire, Alastair Iles, Christopher Bacon, 2012: Diversified farming systems: an agroecological, systems-based alternative to modern industrial agriculture, „Ecology and Society”, nr 17(4), s. 44.

Kudłak Robert, 2010: Wpływ ochrony środowiska na konkurencyjność, „Gospodarka Narodowa”, nr 1-2, s. 109-125.

Kulawik Jacek, 2016: Regulacje środowiskowe i innowacje a konkurencyjność, „Zagadnienia Ekonomiki Rolnej", nr 1(346), s. 3-21.

Kumar Surender, Madhu Khanna, 2009: Measurement of environmental efficiency and productivity: A cross-country analysis, „Environment and Development Economics”, vol. 14, no. 4, s. 473-495.

Kuś Jan, 1995: Systemy gospodarowania w rolnictwie. Rolnictwo integrowane, Materiały szkoleniowe nr 42, IUNG Puławy, s. 3-8.

Kuś Jan, 1999: Efektywność różnych systemów produkcji roślinnej (konwencjonalny, integrowany $i$ ekologiczny), ,Zeszyty Naukowe SGGW w Warszawie. Ekonomika i Organizacja Gospodarki Żywnościowej", nr 37, s. 159-169.

Kuś Jan, Jarosław Stalenga, 2006: Perspektywy rozwoju różnych systemów produkcji rolniczej w Polsce, „Biuletyn Instytutu Hodowli i Aklimatyzacji Roślin”, nr 242, s. 15-25.

López Ramon E., 1994: The Environment as a Factor of Production: The Effects of Economic Growth and Trade Liberalization, „Journal of Environmental Economics and Management”, vol. 27 , s. 163-184.

Luenberger David, 1992: Benefit functions and duality, „Journal of Mathematical Economics”, nr 21, s. 461-481.

Macpherson Alexander, Peter Principe, Elizabeth Smith, 2009: A Production Function Approach to Regional Environmental Economic Assessments, Presented at XI European Workshop on Efficiency and Productivity Analysis, Pisa, Italy, June 24-26. 
Majewski Edward, 2005: Ekonomiczne, środowiskowe i społeczne przesłanki upowszechniania systemu integrowanej produkcji w rolnictwie, [w] Integrowana produkcja droga do żywności bezpiecznej i wysokiej jakości, Wyd. Wieś Jutra, Warszawa, s. 81-94.

Majewski Edward, 2008: Trwaty rozwój i trwałe rolnictwo: Teoria a praktyka gospodarstw rolniczych, Wydawnictwo SGGW, Warszawa, s. 40-55.

Niewęgłowska Grażyna, 2013: Alternatywne formy gospodarowania $w$ rolnictwie wspierane w ramach WPR 2014-2020, Międzynarodowa Konferencja pt. „Nowa polityka rolna UE - kontynuacja czy rewolucja?”, IERiGŻ-PIB, Jachranka, 9-11 grudnia 2013 r.

Niewiadomski Witold, 1993: Rolnictwo jutra, Materiały konferencyjne pt. „Biotyczne środowisko uprawne a zagrożenia chorobowe roślin", ART Olsztyn, s. 9-23.

Nurzyńska Iwona, 2015: Wspólna Polityka Rolna Unii Europejskiej a koncepcja zrównoważonej intensyfikacji rolnictwa, ,, Roczniki Naukowe Stowarzyszenia Ekonomistów Rolnictwa i Agrobiznesu", t. 17, z. 4, s. 2009-214.

Ochrona środowiska w gospodarstwie rolnym. Poradnik dla doradcy, 2010: Centrum Doradztwa Rolniczego w Brwinowie, Oddział w Poznaniu, Poznań, s. 3-50.

OECD, 2011: Green Growth Strategy Workshop, Paris, 10-11 February 2011.

OECD, 2014: Green growth indicators for agriculture - a preliminary assessment, OECD Green Growth Studies, OECD Publishing, s. 8-29, 10-36.

Pawlak Karolina, 2015: Konkurencyjność zasobowa rolnictwa UE i USA, „Zeszyty Naukowe SGGW w Warszawie. Problemy Rolnictwa Światowego", t. 15(XXX), z. 3, s. 112-122.

Piekut Kazimierz, Bogumiła Pawluśkiewicz, 2016: Kierunki rozwoju rolnictwa i obszarów wiejskich w świetle wdrażania Strategii różnorodności biologicznej Unii Europejskiej do 2020 roku, [w] Prawo i polityka ochrony środowiska $w$ doktrynie i praktyce, red. A. Barczak, A. Ogonowska, Rozprawy i Studia Uniwersytetu Szczecińskiego, t. MCVII, nr 943, s. 419-426.

Poczta Walenty, 2015: Wspólna Polityka Rolna wobec koncepcji intensyfikacji i zrównoważonego rozwoju rolnictwa, III Kongres Nauk Rolniczych, Warszawa, 10.09.2015, http://kon-gres.cdr. gov.pl/images/P4_3_Poczta.pdf.

Pruszyński Stefan, Marek Mrówczyński, Grzegorz Pruszyński, 2008: Ochrona roślin w integrowanej technologii produkcji rolniczej, „Problemy Inżynierii Rolniczej”, nr 1/2008, s. 87-98.

Rembisz Włodzimierz, 2008: Mikro- i makroekonomiczne podstawy równowagi wzrostu w sektorze rolno-spożywczym, VIZJA PRESS\&IT, Warszawa, s. 157-280.

Rezek Jon, Richard Perrin, 2004: Environmentally Adjusted Agricultural Productivity in the Great Plains, "Journal of Agricultural and Resource Economics", no. 29(2), s. 346-369.

Shaik Saleem, Richard Perrin, 1999: The Role of Non-parametric Approach in Adjusting Productivity Measures for Environmental Impacts, Presentations, Working Papers, and Gray Literature: Agricultural Economics, Paper No. 30.

Tyteca Daniel, 1996: On the Measurement of the Environmental Performance of Firms - a Literature Review and a Productive Efficiency Perspective, „Environmental Management”, no. 46(3), s. 281-308.

Wiszniewska Elżbieta, 2009: Weryfikacja hipotezy środowiskowej krzywej Kuznetsa na przykładzie Polski. Analiza ekonometryczna, „Studia i Prace Uniwersytetu Ekonomicznego w Krakowie", nr 2, s. 375-387.

Woś Augustyn, 1992: Strategia rozwoju rolnictwa, Wydawnictwo Naukowe PWN, Warszawa, s. 19-69.

Zegar Józef Stanisław, 2005: Koncepcja badań nad rolnictwem społecznie zrównoważonym, [w] Koncepcja badań nad rolnictwem społecznie zrównoważonym, red. J. St. Zegar, Program Wieloletni 2005-2009, nr 11, IERiGŻ-PIB, Warszawa s. 9-22.

Zegar Józef Stanisław, 2007: Społeczne aspekty zrównoważonego rozwoju rolnictwa, „Fragmenta Agroeconomica", nr 4, s. 282-298.

Zegar Józef Stanisław, 2014: Konkurencyjność rolnictwa zrównoważonego, [w] Konkurencyjność polskiej gospodarki żywnościowej w warunkach globalizacji i integracji europejskiej red. A. Kowalski, M. Wigier, Program Wieloletni 2011-2014, nr 147, IERiGŻ-PIB, Warszawa, s. 54-75.

Zieliński Marek, 2014: Emisja gazów cieplarnianych a efektywność funkcjonowania polskich gospodarstw specjalizujacych się w produkcji roślinnej, „Zeszyty Naukowe SGGW w Warszawie. Problemy Rolnictwa Swiatowego", t. 14 (XXIX), z. 3, s. 226-236. 
Żukowska Grażyna, Magdalena Myszura, Stanisław Baran, Sylwia Wesołowska, Małgorzata Pawłowska, Łukasz Dobrowolski, 2016: Agriculture vs. Alleviating the Climate Change, „Problemy Ekorozwoju. Problems of Sustainable Development", no. 2, s. 67-74.

Żylicz Tomasz, 2012: Hipoteza Portera, „Aura”, nr 11, s. 20-21.

http://coin.wne.uw.edu.pl/tzylicz/1211AURA.pdf.

http://dlaklimatu.pl/rolnictwo-przyjazne-klimatowi.

http://piorin.gov.pl/index.php?pid=1477.

http://www.farmer.pl/produkcja-roslinna/ochrona-roslin/jakie-zmiany-czekaja-nas-w-integro-wanejprodukcji-od-2014-r,27097.html.

http://www.konferencjasgh.pl/abstrakty2012/Antczak_Elzbieta.pdf.

http://www.odr.pl/ekologia-i-rodowisko/ochrona-rodowiska/1579-ochrona-srodowiska-w-dzialalnosci-rolniczej, dostęp: 19.09.2016.

http://www.oecd.org/tad/events/environmentally-adjusted-total-factor-productivity-in-agriculture.html.

\section{Justyna Góral, Włodzimierz Rembisz}

\section{PRODUCTION IN AGRICULTURE IN THE CONTEXT OF ENVIRONMENTAL PROTECTION}

\section{SUMMARY}

The main goal of this work was to show the necessity of implementing enviromental aspects into existing agricultural productivity theories. The authors presented the issues of integral productivity and balanced intensification. A new approach to existing measures of farm productivity was discussed as well. Productivity index including environmental aspects (so called Environmentally Adjusted Total Factor Productivity) was showed. European farming, formed by the Common Agricultural Policy, currently implements the ideas of intensification and balanced progress most effectively. At the same time, it is on the development path enabling convergence of these two ideas.

Adres do korespondencji:

Dr Justyna Góral, Prof. dr hab. Włodzimierz Rembisz Instytut Ekonomiki Rolnictwa i Gospodarki Żywnościowej - PIB ul. Świętokrzyska 20, 00-002 Warszawa email: justyna.goral@ierigz.waw.pl,wlodzimierz.rembisz@ierigz.waw.pl 